\author{
MIROSŁAW SADOWSKI \\ ORCID: 0000-0002-0077-8651 \\ Uniwersytet Wrocławski \\ Katedra Doktryn Politycznych i Prawnych
}

\title{
ROZWÓD WEDŁUG PROCEDURY KHULA W PRAWIE EGIPSKIM
}

\begin{abstract}
Abstrakt: Artykuł stanowi analizę egipskiego prawa rozwodowego według procedury khula, ze szczególnym uwzględnieniem ustawy $\mathrm{nr} 1 \mathrm{z} 2000$ roku. Autor stara się wykazać, że uchwalenie tego prawa było krokiem milowym na drodze do równouprawnienia kobiet w prawie małżeńskim. Poprzednie rozwiązania prawne uzależniały uzyskanie rozwodu z inicjatywy żony od spełnienia przez nią szeregu przesłanek lub zgody męża. Nowatorstwo rozwiązań wprowadzonych ustawą nr 1 z 2000 roku polega na tym, że rozwód nie jest uzależniony od zgody męża lub sędziego. Jest on raczej uzależniony od rezygnacji przez żonę z roszczeń finansowych wobec męża przysługujących jej zgodnie z szariatem, które wynikają z kontraktu małżeńskiego lub przepisów prawa.
\end{abstract}

Słowa kluczowe: rozwód według procedury khula, egipskie prawo małżeńskie, Susan Law, egipska ustawa nr 1 z 2000 roku

\section{UWAGI WPROWADZAJĄCE}

Procedura rozwodowa według khula jest jednym ze sposobów rozwiązania małżeństwa w prawie muzułmańskim (prawie islamu, szariacie — pojęcia tożsame). Warto jednak analizę islamskiego prawa małżeńskiego dotyczącą rozwiązania kontraktu małżeńskiego poprzedzić istotną uwagą. Należy nieustannie podkreślać, że w krajach islamskich nie obowiązuje zasada równości wobec prawa, a ludzie są klasyfikowani nie tylko według płci, ale także przynależności religijnej. Istnieją cztery zasadnicze grupy, które mają odmienny status prawny: muzułmanie, wyznawcy religii monoteistycznych, do których należą Żydzi, chrześcijanie, samarytanie i sabejczycy, wyznawcy religii politeistycznych lub nieuznawanych przez islam, jak na przykład bahaici i stojący na równi z nimi ateiści, oraz ostatnia, czwarta grupa - apostaci, to znaczy muzułmanie, którzy odeszli od islamu, dołączając do jednej z wymienionych grup. Można zatem stwierdzić, że prawo islamu nie uznaje zasady równości wobec prawa, ponieważ opiera się na trzech 
nierównościach: pomiędzy muzułmaninem a niemuzułmaninem, pomiędzy mężczyzną a kobietą oraz pomiędzy wolnym a niewolnikiem. $\mathrm{Z}$ punktu widzenia prawa szariat uznaje wyższość muzułmanina nad niemuzułmaninem, podobnie jak wyższość mężczyzny nad kobietą. Dla muzułmanów niższa pozycja kobiet zapisana jest w Koranie, na przykład sura II werset 228 głosi: „One mają prawa równe swoim obowiązkom, zgodnie z uznanym zwyczajem ${ }^{1}$. Mężczyźni mają nad nimi wyższość ${ }^{2}$. Przykładowo można wskazać poniższe różnice: zeznania jednego mężczyzny równoważą zeznania dwóch kobiet, tylko mężczyzna może mieć cztery żony, tylko muzułmanin mężczyzna może poślubić niemuzułman$\mathrm{kę}^{3}$, muzułmanka nie może poślubić niemuzułmanina, kobieta dziedziczy połowę tego, co mężczyzna, dzieci zawsze przyjmują religię ojca. Konstytucje krajów islamskich zawierają normy, z których jednoznacznie wynika, że głową takiego państwa może być tylko muzułmanin ${ }^{4}$. Można zatem postawić tezę, że muzułmanie akceptują nierówny status prawny ze względu na płeć lub wyznawaną religię.

Warto wiedzieć, że we wszystkich państwach, w których islam jest religią dominującą, jedynym obowiązującym prawem rodzinnym jest szariat ${ }^{5}$. W wymienionych krajach prawo stanowione w sferze prawa rodzinnego nie tylko jest zgodne, ale także wprost bazuje na szariacie. Tym samym opiera się na rozwiązaniach wypracowanych ponad tysiąc lat temu, ponieważ normy prawne regulujące kwestie zawarcia i ustania małżeństwa zostały zawarte w Koranie i sunnie (tradycji) proroka Mahometa - tekstach, które powstawały pomiędzy VII a IX wiekiem. Co znamienne, rozwiązania te są wciąż aktualne i mają wpływ na życie ponad miliarda siedmiuset milionów ludzi. $\mathrm{Z}$ tych powodów warto stale przypominać, że prawo rodzinne w większości krajów muzułmańskich jest zdominowane przez tradycyjne prawo islamskie.

Muzułmanie odrzucają celibat, a małżeństwo uważają za religijno-prawny nakaz, którego wykonanie jest często wymuszane przez bardzo silną presję społeczną. W społecznościach muzułmańskich trudno było spotkać osoby niepozostające (lub takie, które nie pozostawały w nim wcześniej — rozwiedzionych, owdo-

${ }^{1}$ Muzułmanie przekonują, że w islamie mężczyzna ma znacznie więcej obowiązków, zatem zgodnie z zapisem koranicznym logiczne jest, że ma także więcej praw.

2 Wszystkie cytaty z Koranu za: Koran, z arabskiego przełożył i komentarzem opatrzył J. Bielawski, Warszawa 1986. Cyfra rzymska oznacza surę (rozdział Koranu), a arabska - ajat (werset).

${ }^{3}$ Szariat zezwala muzułmaninowi na poślubienie kobiet zaliczanych do tak zwanych „ludów księgi”, czyli żydówek i chrześcijanek. Szerzej na temat relacji rodzinnych w przypadku małżeństwa muzułmanina z niemuzułmanką por. U. Shavit, Shari'a and Muslim Minorities. The wasati and salafi approaches to fiqh al-aqalliyyat al-Muslima, Oxford 2015, s. 158-166.

4 Tego typu postanowienia występują między innymi w konstytucjach Jordanii, Kataru, Kuwejtu, Algierii, Afganistanu, Jemenu, Iranu; ibidem. Por. szerzej w tej kwestii Z. Landowski, Polityczny wymiar islamu we wspótczesnych konstytucjach, Warszawa 2013, s. 185-189.

5 J.N.D. Anderson, Modern trends in Islam legal reform and modernisation in the Middle East, „International \& Comparative Law Quarterly” 20, 1971, ner 1, s. 1-21, supra note 1, at 1. 
wiałych) w związku małżeńskim ${ }^{6}$. Zgodnie z szariatem małżeństwo jest jedynym legalnym (inaczej halal - dozwolonym przez prawo) sposobem zaspokajania popędu seksualnego pomiędzy mężczyzną i kobietą. Wszystkie pozamałżeńskie kontakty seksualne są zakazane, a cudzołóstwo jest nie tylko grzechem, lecz także jednym z najcięższych przestępstw i podlega bardzo surowym sankcjom? ${ }^{7}$.

Islamskie prawo małżeńskie wyraźnie faworyzuje mężczyznę, ponieważ zezwala na poligynię, to jest związek jednego mężczyzny z kilkoma kobietami (maksymalnie czterema) ${ }^{8}$, ale całkowicie zakazuje poliandrii, zatem związku jednej kobiety z co najmniej dwoma mężczyznami. Gwoli ścisłości należy zauważyć, że niektóre kraje, na przykład Turcja i Tunezja, zakazały poligamii9.

Prawo rodzinne w krajach islamskich regulowane jest na podstawie szariatu i za pomocą wielu instytucji tak zwanego ,prawa statusu osobistego" ${ }^{10}$. Jest to dziedzina prawa, która oprócz prawa rodzinnego obejmuje także normy dotyczące zdolności prawnej, opieki, kurateli, spadkobrania i testowania ${ }^{11}$.

Szariat traktuje małżeństwo jako zwykły kontrakt z zastrzeżeniem pewnych warunków. Pierwszy, akceptowany przez wszystkie cztery szkoły prawa, stanowi, że przy podpisywaniu kontraktu małżeńskiego musi być obecna określona liczba świadków. Drugi warunek to jednoznaczne potwierdzenie przez mężczyznę i kobietę, że zamierzają zawrzeć związek małżeński i stać się mężem i żoną ${ }^{12}$.

${ }^{6}$ Ostatnie lata przynoszą istotne zmiany w tej materii, ponieważ spotyka się coraz więcej samotnych, wykształconych kobiet, które nie mogą wyjść za mąż bez złamania zasady równości mężczyzny wobec kobiety. Zgodnie z tą zasadą mężczyzna musi posiadać status społeczny, ekonomiczny czy wykształcenia co najmniej na takim samym poziomie jak kobieta. Ponieważ w krajach muzułmańskich wykształconych mężczyzn jest mniej niż wykształconych kobiet, tym ostatnim nie jest łatwo znaleźć odpowiedniego kandydata.

7 Jeszcze dziś w niektórych krajach muzułmańskich (na przykład w Afganistanie, Pakistanie, Nigerii, Arabii Saudyjskiej czy Iranie) kobieta, która popełniła cudzołóstwo, może być skazana na śmierć przez ukamienowanie. Por. E. Peiffer, The death penalty in traditional Islamic law and as interpreted in Saudi Arabia and Nigeria, „William \& Mary Journal of Women and the Law” 11, 2005, nr 3, s. 507-539.

${ }^{8}$ Szerzej na temat współczesnego postrzegania poligamii przez muzułmanów zob. N.M. Wardeh, Rethinking polygamy in Islamic exegetical discourse, „International Journal of Arts \& Sciences” 09, 2016, nr 03, s. 413-426; oraz H. Syed Jaffer, Legal modernism in Islam: Polygamy and repudiation, „Journal of the Indian Law Institute” 7, October-December 1965, nr 4, s. 384-398.

9 Por. Article 112 (1) of the Turkish Civil Code, 1926 and Article 18 of the Tunisian Code of Personal Status, 1956, [w:] R.K. Sinha, Muslim Law, Allahabad 2003, s. 39. Należy też pamiętać, że poligynia jest dopuszczalna, ale nie jest obowiązkowa. Por. też L.R. Sjukijajnen, który stwierdził, że ustawodawstwo prawie wszystkich krajów arabskich zezwala muzułmańskiemu mężczyźnie na posiadanie czterech żon - idem, Prawo muzutmańskie i ustawodawstwo rodzinne krajów Arabskiego Wschodu, [w:] idem, Prawo muzulmańskie. Struktura i podstawowe instytucje, Warszawa 1990, s. 226.

${ }^{10}$ Szerzej w tej materii por. M. Sadowski, Matżeństwo w prawie islamu, Poznań 2015, s. 29-30.

11 Tak też L.R. Sjukijajnen, op. cit., s. 210.

12 M. Wohidul Islam, Dissolution of contract in Islamic law, „Arab Law Quarterly” 336, 1998, s. 353.

Przegląd Prawa i Administracji CXX, 2020, cz. 1 i 2

(C) for this edition by CNS 
Mimo że małżeństwo w prawie islamu jest umową cywilnoprawną, to instytucja ta jest głęboko osadzona w religii i trudno uznać ją za czysto świecki akt w sensie ślubów cywilnych w rozumieniu cywilizacji Zachodu ${ }^{13}$. Zawarty na podstawie szariatu kontrakt małżeński wprost zawiera szereg odniesień do religii ${ }^{14}$, a wszystkie jego postanowienia muszą być z nią zgodne.

\section{ROZWIĄZANIE MAŁŻEŃSTWA WEDŁUG SZARIATU}

Jak wiadomo, dla muzułmanów małżeństwo jest kontraktem, który zawierany jest pomiędzy mężczyzną a kobietą — i tak jak każdy kontrakt, po spełnieniu określonych warunków, może być rozwiązane ${ }^{15}$. Prawo muzułmańskie zna kilka form rozwiązania małżeństwa:

— z inicjatywy męża,

— z inicjatywy żony,

— za obopólnym porozumieniem,

$\mathrm{w}$ drodze postępowania sądowego ${ }^{16}$.

Warto jednak wiedzieć, że zgodne z szariatem rozwiązanie małżeństwa różni się od rozwodu w tradycji prawnej Okcydentu. Ludziom Zachodu trudno sobie wyobrazić, że w prawie muzułmańskim kobieta i mężczyzna nie mają równych praw w przypadku chęci rozwiązania związku małżeńskiego. W prawie islamu możliwość przeprowadzenia rozwodu w przeważającej mierze zależna jest od płci osoby, która z takim żądaniem występuje. Mężczyzna ma przy tym niemal niczym nieograniczoną możliwość rozwiązania małżeństwa poprzez rozwód ${ }^{17}$. Gdy dokonuje tej czynności w formie talaq ${ }^{18}$, nie wymaga się od niego podania jakiejkolwiek przyczyny. Z kolei kobieta pragnąca uzyskać rozwód może go otrzymać po spełnieniu wielu, często upokarzających warunków ${ }^{19}$. Druga istotna różnica polega na tym, że szariat — obok wyłącznej w tradycji Zachodu drogi sądowej

13 Por. też w tej materii K. Spencer, Mahr as contract: internal pluralism and external perspectives, „Oñati Socio-Legal Series” 1, 2011, nr 2, s. 3.

14 W każdym kontrakcie, już na początku jego treści zaznaczono, że zawarty jest w „imię Allaha".

15 Por. B.M. Khir, The Right of Women to No-Fault Divorce in Islam and Its Application by British Muslims, „Islam and Christian - Muslim Relation” 17, 2006, nr 3, s. 296.

16 D. Perl, W. Menski, Muslim Family Law. Third Edition, London 1998, s. 279.

17 Nie do przyjęcia są konstatacje Aldony Piwko, która błędnie twierdzi, że rozwód w islamie wymaga skomplikowanych procedur formalnych. Por. eadem, Rozwód w islamie, „Nurt SVD”, wydanie specjalne 2013, s. 48.

18 Odnośnie do tego zagadnienia por. M. Sadowski, Rozwód wedtug procedury talaq w prawie islamu, „Radca Prawny: Zeszyty naukowe” 2017, nr 3, s. 35-53.

19 Szerzej w tej materii por. N. Sonneveld, The implementation of the ,khul' law" in Egyptian courts some preliminary results, „Recht van de Islam” 21, 2004, s. 21-35. 
— dopuszcza również pozasądowe, ,prywatne” procedury rozwodowe, w których droga sądowa nie występuje.

Należy wiedzieć, że chociaż rozwód w prawie islamu jest legalny, to muzułmańscy juryści przekonują, że należy on do kategorii czynów niepożądanych. Zgodnie z islamską tradycją Mahomet miał powiedzieć, że z wszystkich dozwolonych przez Allaha rzeczy najobrzydliwszy jest rozwód ${ }^{20}$.

Pomimo tych obostrzeń instytucja ta funkcjonuje $\mathrm{w}$ ramach prawa islamu ${ }^{21}$ i to $\mathrm{w}$ wielu różnych formach. Warto podkreślić, że implementacja norm szariatu do ustawodawstwa wszystkich państw arabskich za fundamentalną formę rozwiązania małżeństwa uznaje rozwód, a w tej materii prawie nieograniczone uprawnienie ma mąż. Dla przykładu można wskazać, że ustawodawstwo wielu krajów muzułmańskich stwierdza wprost - pełnoletni i mający pełną zdolność do czynności prawnych mąż może w każdym czasie, stosownie do swej woli, rozwieść się z żoną bez podania jakiejkolwiek przyczyny.

Aby pokazać specyfikę ustania małżeństwa w szariacie według procedury khula, wskażę inne procedury prowadzące do rozwiązania małżeństwa w tym systemie prawnym. Zaliczamy do nich: talaq — rozwód z inicjatywy męża; mubaraat - rozwód za porozumieniem stron (obopólne wyzwolenie); ila — rozwód na mocy przysięgi dokonanej przez męża, w której oświadcza on, że nie będzie współżył z żoną przez cztery miesiące (przysięga celibatu); zihar — rozwód polegający na odrzuceniu żony przez męża poprzez wygłoszenie przez niego następujących słów: ,jesteś dla mnie jak plecy mojej matki ${ }^{22}$ "; lian — rozwód polegający na wzajemnym oskarżeniu małżonków, mąż czterokrotnie oskarża żonę o cudzołóstwo, żona natomiast czterokrotnie przysięga, iż to nieprawda (wspólne przekleństwo) ${ }^{23}$; tafrik — separacja orzekana sądowo; fasakh — rozwód orzekany sądowo, rozwiązanie małżeństwa z mocy prawa ${ }^{24}$.

Najczęściej spotykaną formą rozwodu w prawie islamu jest talaq (repudiacja), drugą, znacznie rzadziej stosowaną procedurą rozwodową jest khula (thuma-

20 Por. S. Sultan, The Qur'an and Sayings of Prophet Muhammad: Selections Annotated \& Explained, Woodstock 2012, s. 200.

${ }^{21}$ Na przykład odsetek rozwodów w stosunku do zawartych małżeństw w krajach Zatoki Perskiej waha się od 20\% w Arabii Saudyjskiej do przedziału 34-46\% w takich krajach, jak Bahrajn, Kuwejt, Katar czy Zjednoczone Emiraty Arabskie; przytaczam za: L. Anser, Divorce in the Arab Gulf Countries. A Major Challenge to Family and Society, s. 65, https://www.academia. edu/6629935/Divorce_in_the_Arab_Gulf_Countries_A Major_Challenge_to_Family_andSociety?auto=download (dostęp: 31.07.2017).

${ }^{22}$ Legitymacja dla tego typu rozwodu pochodzi wprost z Koranu: On nie uczynił dwóch serc we wnętrzu człowieka. On nie uczynił waszych żon, z którymi się rozwodzicie, mówiąc: „Ty jesteś dla mnie jak grzbiet mojej matki!" — waszymi matkami, Koran XXXIII-4.

${ }^{23} \mathrm{Z}$ taką możliwością mamy do czynienia w sytuacji, w której nie ma dowodów na cudzołóstwo, zatem na przykład świadków.

24 Szeroko w tej kwestii: M. Mehrajuddin, Divorce under Islamic Law, „Cochin University Law Review" 9, 1985, s. 317-349. Por. też J.J.A. Nasir, The Status of Women under Islamic Law and Modern Islamic Legislation, Leiden-Boston 2009, s. 117-158. 
czone jako „wydobycie rzeczy z innej rzeczy”, w znaczeniu dosłownym — ,ściągać ubranie") — rozwód inicjowany przez żonę będący swego rodzaju transakcją — w zamian za rozwód żona zobowiązuje się do wypłaty mężowi odpowiedniego wynagrodzenia ${ }^{25}$. Istotą khula jest możliwość rozwiązania małżeństwa z inicjatywy żony bez podawania konkretnych przesłanek świadczących o winie męża wystarczy, że stwierdzi ona, iż dalsze życie u boku małżonka jest dla niej nie do zniesienia ${ }^{26}$. Za podstawę khula uznaje się wers Koranu w brzmieniu:

Rozwód jest możliwy dwa razy. Potem więc albo ją zatrzymacie, zgodnie ze zwyczajem, albo dacie jej całkowitą wolność, uprzejmie ją traktując. Nie jest wam dozwolone zabierać cokolwiek z tego, coście dali swoim żonom. Chyba że oboje się obawiają, że nie potrafią zachować granic ustanowionych przez Boga. Jeśli się obawiacie, że nie potrafią zachować granic Boga, to oni oboje nie będą mieli grzechu, jeśli ona się wykupi. Takie są granice Boga! Nie przekraczajcie ich! Ci, którzy przekraczają granice Boga, są niesprawiedliwi ${ }^{27}$.

Khula, w przeciwieństwie do talaq, nie jest skuteczne od razu po wypowiedzeniu odpowiedniej formułki przez żonę — gdy uzna, że dalsze małżeństwo jest niemożliwe, może poprosić męża o rozwód khula. Rozwód ten będzie skuteczny, dopiero gdy mąż wyrazi na niego zgodę (co powinien uczynić podczas tego samego spotkania, podczas którego żona poprosiła o khula). W zamian za to, żona zobligowana jest do wypłaty mężowi określonego datku (może być nim wszystko, co jest według prawa islamu dopuszczane jako mahr — dar męża dla żony), choć wskazuje się, że może nastąpić sytuacja, gdy mąż zgodzi się na khula bez żądania zapłaty. Zapłata może być określoną darowizną lub po prostu równowartością $m a h r u^{28}$. Aby rozwód khula był ważny, mąż musi posiadać prawną zdolność do wypowiedzenia rozwodu, a żona musi być pełnoprawnym podmiotem, wobec którego mąż posiada uprawnienie ${ }^{29}$. Oboje muszą być zdrowi na umyśle oraz być zdolni do czynności prawnych (osiągnąć wiek dojrzałości). Jednocześnie żadna szczególna forma nie jest wymagana — żona może poprosić o khula po prostu poprzez użycie tego sformułowania lub w jakiejkolwiek innej formie wskazującej na chęć dokonania tej „transakcji”30. W wypadku gdy mąż nie zgodzi się na rozwód i między małżonkami nie dojdzie do porozumienia, żona ma prawo wystąpić

25 Por. J. Schacht, An introduction to Islamic law, Oxford 1982, s. 164.

${ }^{26}$ Wskazuje się, że tradycja istnienia khula ma swoje korzenie w czasach Proroka, a pierwszy przypadek khula związany jest z żoną Thabita ibn Qays'a. Będę o tym pisał w dalszej części artykułu. Por. B.M. Khir, op. cit., s. 296-297.

27 Koran, II-229.

28 Szerzej zob. N.C. Rao, The Impact of Legislation on Marriage and Divorce under Hindu and Muslim Laws, Acharya Nagarjuna 2011, s. 253-255; S.I. Sham, Some Aspects of Marriage and Divcorce in Muslim Family Law, Punjab 2011, s. 31, http://pu.edu.pk/images/journal/szic/ currentissue_pdf/E-1\%20Shehza\%20sham\%20(Islamic\%20Law $\% 20$ of $\% 20$ Marriage $\% 20$ and $\% 20$ Divorce).pdf (dostęp: marzec 2014).

29 Por. J.J. Nasir, The Islamic Law of Personal Status, London 1990, s. 123.

30 Por. N.C. Rao, op. cit., s. 254-255. 
o khula do sądu ${ }^{31}$. Sędzia ma obowiązek wysłuchania woli kobiety i - jeśli wypełnia ona przesłanki do otrzymania khula - jest zobowiązany orzec rozwód ${ }^{32}$, choć najpierw powinien skierować do małżonków dwóch arbitrów, którzy dokonają próby ich pogodzenia ${ }^{33}$. Wskazuje się jednak, iż wymaganie uzyskania zgody od męża na rozwód oraz perspektywa drogi sądowej często de facto zamyka kobietom drogę do uzyskania rozwodu i to zarówno w przypadku małżeństw pozbawionych miłości, jak i takich, w których występuje przemoc ze strony partnera ${ }^{34}$. Ponadto przeszkodą jest wymóg wypłacenia mężowi odszkodowania (najczęściej równowartości mahru), co ogranicza możliwość uzyskania khula jedynie kobietom o wystarczająco wysokim statusie ekonomicznym ${ }^{35}$.

\section{KHULA W PRAWIE EGIPSKIM}

Egipskiemu prawu rodzinnemu brakuje kompleksowej kodyfikacji. Oprócz pochodzących ze szkoły hanafickiej ${ }^{36}$ reguł klasycznego szariatu regulowane jest ono również normami prawa stanowionego. Wymienić można tutaj następujące akty prawne:

— ustawa nr 25 z 1920 roku w sprawie alimentów i niektórych kwestii dotyczących statusu osobistego,

— ustawa nr 25 z 1929 roku w sprawie niektórych przepisów dotyczących statusu osobistego,

— ustawa $\mathrm{nr} 77$ z 1943 roku w sprawie dziedziczenia,

— ustawa $\mathrm{nr} 71$ z 1946 roku dotycząca zapisów testamentowych,

— ustawa nr 62 z 1976 roku zmieniająca niektóre zasady dotyczące zasiłków inwalidzkich,

— ustawa nr 100 z 1985 roku zmieniająca ustawy nr 25 z 1920 i 1929 roku,

31 Część doktryny uważa, że khula możliwy jest wyłącznie na drodze sądowej, jednak większość szkół (Malikici, Hanbalici, Szafici) uznaje khula za rozwód bez ingerencji sądu. We współczesnym prawie muzułmańskim obserwuje się trzy podejścia: khula jako rozwód bez ingerencji sądu, khula jako rozwód bez lub z ingerencją sądu oraz khula dopuszczany wyłącznie z ingerencją sądu. Por. B.M. Khir, op. cit., s. 298-299.

32 Por. S.I. Sham, op. cit., s. 32-33.

33 Por. B.M. Khir, op. cit., s. 300.

${ }^{34}$ Szerzej zob. J. Hussain, Islam. Its Law and Society, Sydney 2004, s. 103-104, 106-107, [za:] J. Balicki, Imigranci z krajów muzułmańskich w Unii Europejskiej. Wyzwania dla polityki integracyjnej, Warszawa 2010, s. 241-242; H. Abdalati, Spojrzenie w islam, 1993, s. 238, [za:] J. Balicki, op. cit., s. 241.

35 Problem ten został podkreślony w raporcie Human Rights Watch w odniesieniu do Egiptu. Szerzej zob. F. Deif, Divorce from Justice: Women's Unequal Access to Divorce in Egypt, t. 16, nr 8, New York 2004.

36 W kwestii szkół prawa w islamie sunnickim por. R. Peters, The Islamic School of Law: Evolution, Devolution, and Progress, red. P. Bearman, R. Peters, F.E. Vogel, Cambridge, Massachusetts 2005, passim. 
- ustawa $\mathrm{nr} 12$ z 1996 roku w sprawie praw dziecka zmieniona ustawą nr 126 z 2008 roku,

— ustawa nr 1 i ustawa nr 91 z 2000 roku określające warunki i procedury dotyczące małżeństwa Urfi i rozwodu khula,

— ustawa nr 10 z 2004 roku ustanawiająca sądy rodzinne,

- ustawa nr 11 z 2004 roku ustanawiająca Fundusz ubezpieczeń rodzinnych (w celu zaliczek na świadczenia alimentacyjne),

— ustawa nr 4 z 2005 roku zmieniająca art. 20 w ustawie nr 25 z 1920 roku dotyczący podniesienia wieku opieki,

- ustawa nr 126 z 2008 roku dotycząca zmian w kwestii praw dziecka.

Jak trafnie wskazała Nathalie Bernard-Maugiron, od XX wieku egipskie prawo rodzinne dąży do przywrócenia równowagi w dostępie kobiet i mężczyzn do rozwiązania małżeństwa ${ }^{37}$. Droga do osiągnięcia tej równowagi jest jednak bardzo wyboista i kręta. Pomimo pewnych zmian na korzyść kobiet, jakie przyniosły ustawy z 1920, 1929 i 1985 roku, dopiero ustawa nr 1 z 2000 roku okazała się przełomowa, jeśli chodzi o uzyskanie rozwodu z inicjatywy kobiety bez zgody męża ${ }^{38}$.

Do czasu przyjęcia tego rewolucyjnego aktu prawnego kobieta miała bardzo ograniczone możliwości uzyskania rozwodu. Zgodnie z prawem szkoły hanafickiej żona mogła uzyskać sądowy rozwód tylko w przypadku niezdolności męża do skonsumowania małżeństwa, jego apostazji lub w sytuacji „,nieuczciwego małżeństwa", to znaczy zawartego przed uzyskaniem dojrzałości płciowej ${ }^{39}$.

Pierwszym aktem prawnym, który poprawił położenie prawne kobiety, była ustawa nr 25 z 1920 roku. Zezwoliła ona żonie na złożenie wniosku do sądu o rozwód, jeśli jej mąż nie był w stanie wywiązywać się ze swoich zobowiązań finansowych względem żony, był nieobecny przez określony czas lub odmawiał zapłaty i nie miał widocznych aktywów, dzięki którym można by zaspokajać prawa przysługujące żonie. Ponadto żona mogła wystąpić z żądaniem rozwodu, gdy u męża stwierdzono długotrwałą lub nieuleczalną chorobę, która mogłaby przynieść szkodę żonie, gdyby ta dłużej pozostawała w związku małżeńskim ${ }^{40}$.

Druga ustawa - nr 25 z 1929 roku — dopuszczała rozwód na wniosek żony, jeśli doznała ona szkody z powodu długotrwałej i nieuzasadnionej nieobecności męża (przez rok lub dłużej), na przykład jeśli mąż został skazany na trzy lata lub

37 Zob. N. Bernard-Maugiron, Courts and the reform of personal status law in Egypt: judicial divorce for injury and polygamy, [w:] Adjudicating Family Law in Muslim Courts, red. E. Giunchi, New York 2014, s. 106.

38 J. Moussa nie zawahał się stwierdzić, że ta ustawa zmierza w kierunku równości kobiety i mężczyzny w prawie rozwodowym; por. The Reform of Shari'a-derived Divorce Legislation in Egypt: International Standards and the Cultural Debate, www.nottingham.ac.uk/shared/shared_hrlcpub/HRLC_Commentary_2005/MOUSSA.pdf (dostęp: 12.05.2012).

39 Ibidem.

40 Art. 4, 5, 9 ustawy nr 25 z 1920 roku jako przykłady nieuleczalnej choroby (lub uleczalnej dopiero po długim czasie) wskazywały trąd i szaleństwo. 
więcej więzienia mogła, po upływie pierwszego roku pozbawienia wolności, wystąpić z wnioskiem o rozwód ${ }^{41}$. Jako podstawę prawną wskazywano szkodę, jaką mogłaby ponieść żona, gdyby dłużej pozostawała w tym związku małżeńskim.

Dopiero wykazanie takiej szkody, niezwykle trudne do przeprowadzenia, uprawniało żonę do rozwodu sądowego ${ }^{42}$. Jeżeli żona nie była w stanie udowodnić szkody, nie uzyskiwała rozwodu z powodu braku tej przesłanki. Jeśli jednak ponownie wystąpiła ze swoim roszczeniem $z$ tych samych powodów, prawo przewidywało wszczęcie postępowania mediacyjnego przez sąd z udziałem dwóch arbitrów (najlepiej z rodzin małżonków), którzy próbowali pogodzić małżonków ${ }^{43}$. Jeśli próby pojednania nie przyniosłyby efektu, a mediatorzy uznaliby, że wina leży po stronie męża lub obu stron, lub nie można by było tego jednoznacznie stwierdzić, mogli orzec ostateczny rozwód ${ }^{44}$. Ustawa nr 100/1985, przyjęta dwa miesiące po orzeczeniu Egipskiego Trybunału Konstytucyjnego, że ustawa nr 44/1979 była niekonstytucyjna, upoważniła żonę do rozwodu z mężem w przypadku jego poligamii, nawet jeśli umowa małżeńska nie przewidywała, że nie może on poślubić innej osoby. Jednakże żona musiała udowodnić, że drugie małżeństwo jej męża spowodowało jej fizyczną lub moralną szkodę, w taki sposób, że utrudniało to dalsze pożycie małżeńskie pomiędzy nimi ${ }^{45}$. Przytoczone analizy wskazują, że przed ustawą nr 1 z 2000 roku podstawą do rozwodu inicjowanego przez żonę była przesłanka szkody i dopiero tak zwane Susan Law ${ }^{46}$ wprowadziło procedurę sądową umożliwiającą kobiecie uzyskanie rozwodu bez wykazania szkody. Wymieniona ustawa zezwalała żonie na udanie się do sądu w celu uzyskania sądowego rozwiązania ich małżeństwa, a sędzia nie mógł odmówić prośbie żony, nawet w sytuacji sprzeciwu męża. Deklaracja żony, że nie znosi ona wspólnego mieszkania, ponieważ mąż stał się dla niej tak wstrętny, że może ona przekroczyć „granice Boga”, jeśli pozostaną razem, uprawniała żonę do wystąpienia o rozwód. Ustawodawca egipski odwoływał się wprost do znanego hadisu, w którym ibn Abbas (kuzyn Proroka i powszechnie uznany autorytet) opowiadal, jak Habiba,

żona Thābina bin Qaysa przyszła do Proroka i powiedziała: „O, Allahu! Widzę nie ma winy w charakterze Thābina ani jego religii, ale ja, będąc muzułmanką mogę przekroczyć granice Boga (jeśli pozostanę przy nim)”. Apostoł Allaha powiedział (jej): „Oddasz mu z powrotem ogród, który

41 Art. 12-14 ustawy nr 25 z 1929 roku.

42 Por. H. Fahmi, Divorcer en Egypte: Etude de l'application des lois du statut staff, Kair 1987, s. 21-23.

43 Art. 7, 8 ustawy nr 25 z 1929 roku.

44 Por. art. 7, 8, 9 ustawy nr 25 z 1929 roku. Art. 9 ustawy nr 25 z 1929 roku; oraz J.N.D. Anderson, Recent developments in Shari'a law (V): The dissolution of marriage', „The Muslim World” 41, 1951, nr 4, s. 286.

45 N. Bernard-Maugiron, op. cit., s. 111-112.

46 W literaturze określa się ustawę z 2000 roku jako „Susan Law” — od imienia żony prezydenta Egiptu Hosniego Mubaraka, Susan, która była bardzo zaangażowana w przyjęcie tej ustawy. 
podarował ci twój mąż [jako mahr]?” Powiedziała: „Tak”. Prorok rzekł do Thābina: „Przyjmijj (iqbal) swój ogród i rozwiedź się z nią raz (talliqhā) $)^{47}$ ".

Przykład dobitnie pokazuje, że zasady islamskiego prawa małżeńskiego wypracowane przed ponad 1000 lat są ciągle aktualne. Dlatego też w takim przypadku żona nie musi udowadniać szkody, ale powinna zrezygnować ze swoich roszczeń finansowych wobec męża, które przysługiwałyby jej w przypadku rozwodu według procedury talaq ${ }^{48}$. Artykuł 20 analizowanej ustawy uzależnia rozwód $k h u$ la od próby pojednania małżonków. Jeżeli małżonkowie nie zostaną pogodzeni, sędzia ,jest zobowiązany do ogłoszenia rozwodu, nawet wbrew woli męża”. Próba pojednania jest przeprowadzana przez dwóch mediatorów wyznaczonych przez sąd i nie może przekraczać trzech miesięcy. W przypadku gdy para ma dzieci, może dojść do drugiej próby pojednania prowadzonej przez trzy osoby, a ta druga próba nie może przekroczyć trzydziestu dni ${ }^{49}$.

$\mathrm{Z}$ całym przekonaniem można stwierdzić, że w ustawie z 2000 roku kluczowe znaczenie ma art. 20, zgodnie z którym rozwód dokonany poprzez khula, w przeciwieństwie do rozwodu sądowego w oparciu o przesłankę szkody, jest jednokrotnym, nieodwołalnym rozwodem i nie podlega zaskarżeniu ${ }^{50}$.

Co prawda procedura, która pozwalała kobietom na rozwiązanie małżeństwa w zamian za rekompensatę finansową, była znana w prawie egipskim przed 2000 roku. Jednakże ta wcześniejsza procedura rozwodowa miała miejsce przed urzędnikiem stanu cywilnego, a nie przed sędzią, i była warunkowana wyraźną zgodą męża i rodzajem polubownego „rozdzielenia” małżeństwa lub wspólnym wnioskiem o rozwód ${ }^{51}$. Bez wątpienia nowatorstwo rozwiązań wprowadzonych ustawą nr 1 z 2000 roku polega na tym, że rozwód nie jest uzależniony od zgody męża lub sędziego. Jest on raczej uzależniony od rezygnacji przez żonę z przysługujących jej zgodnie z szariatem roszczeń finansowych wobec męża, które wynikają z kontraktu małżeńskiego lub przepisów prawa. Ponadto żona może zostać zobowiązana do wypłacenia mężowi odszkodowania w zamian za szybsze przeprowadzenie rozwodu. Zdesperowane kobiety często decydują się na taki krok. Jeśli żona spełnia te warunki, powinna otrzymać nieodwołalny rozwód w okresie nieprzekraczającym trzech miesięcy.

W mojej ocenie, z punktu widzenia autora okcydentalnego, pomimo swoich skromnych rozwiązań prawo do rozwodu według procedury khula z 2000 roku stanowi krok milowy w poprawie sytuacji prawnej kobiety we współczesnym Egipcie. Przekonuje o tym fakt, że od czasu jego przyjęcia ponad milion Egipcjanek zdecydowało się skorzystać z tej możliwości.

47 Por. Sahih al-Buchari, http://www.sahihalbukhari.com/sps/sbk/ (dostęp: 10.11.2014).

${ }^{48}$ Szerzej w tej kwestii por. M. Sadowski, Rozwód wedlug procedury talaq..., s. 35-53.

49 N. Sonneveld, Khul divorce in Egypt. How family courts are providing a dialogue between husband and wife, „Anthropology of the Middle East” 5, 2010, nr 2, s. 103.

50 J. Moussa, op. cit.

51 Por. N. Bernard-Maugiron, op. cit., s. 113. 


\section{KHULA PROCEDURE DIVORCE IN EGYPTIAN LAW}

\section{Summary}

The article is devoted to an analysis of Egyptian divorce law under the khula procedure with a particular focus on Law no. 1 from 2000. The author ventures to show that the establishment of this act was a milestone on the road to the equality of women's rights in marital law. Earlier regulations only allowed for a divorce initiated by the woman under a number of conditions or with her husband's consent. The main innovation of Law no. 1 from 2000 is that the divorce can be granted without the consent of either the husband or the judge. It is contingent on the wife's resignation from any financial claims she might have towards her husband according to Sharia law, either under a marriage contract or existing legal regulations.

Keywords: divorce under the khula procedure, Egyptian marital law, Susan Law, Egyptian law no. 1 from 2000

\section{BIBLIOGRAFIA}

Anderson J.N.D., Modern trends in islam legal reform and modernisation in the Middle East, „International \& Comparative Law Quarterly" 20, 1971, nr 1, s. 1-21.

Anderson J.N.D., Recent Developments in Shari'a law (V): The dissolution of marriage', „The Muslim World" 42, 1951, nr 4.

Anser L., Divorce in the Arab Gulf Countries. A Major Challenge to Family and Society, https:// www.academia.edu/6629935/Divorce_in_the_Arab_Gulf_Countries_A Major_Challenge_to_ Family_andSociety?auto=download (dostęp: 31.07.2017).

Balicki J., Imigranci z krajów muzulmańskich w Unii Europejskiej. Wyzwania dla polityki integracyjnej, Warszawa 2010.

Bernard-Maugiron N., Courts and the reform of personal status law in Egypt: judicial divorce for injury and polygamy, [w:] Adjudicating Family Law in Muslim Courts, red. E. Giunchi, New York 2014.

Deif F., Divorce from Justice: Women's Unequal Access to Divorce in Egypt, New York 2004.

Fahmi H., Divorcer en Egypte: Etude de l'application des lois du statut staff, Kair 1987.

Hallaq W.B., What is Shari'a?, [w:] Yearbook of Islamic and Middle Eastern Law, t. 12, 2005-2006, Leiden 2007.

Khir B.M., The Right of Women to No-Fault Divorce in Islam and Its Application by British Muslims, „Islam and Christian - Muslim Relation” 17, 2006, nr 3.

Koran, z arabskiego przełożył i komentarzem opatrzył J. Bielawski, Warszawa 1986.

Landowski Z., Polityczny wymiar islamu we współczesnych konstytucjach, Warszawa 2013.

Mehrajuddin M., Divorce under Islamic law, „Cochin University Law Review” 9, 1985, s. 317-349.

Moussa J., The Reform of Shari'a-derived Divorce Legislation in Egypt: International Standards and the Cultural Debate, www.nottingham.ac.uk/shared/shared_hrlcpub/HRLC_Commentary_2005/MOUSSA.pdf.

Nasir J.J., The Islamic Law of Personal Status, London 1990.

Nasir J.J.A., The Status of Women under Islamic Law and Modern Islamic Legislation, Leiden-Boston 2009.

Peiffer E., The death penalty in traditional Islamic law and as interpreted in Saudi Arabia and Nigeria, „William \& Mary Journal of Women and the Law” 11, 2005, nr 3, s. 507-539.

Perl D., Menski W., Muslim Family Law. Third Edition, London 1998. 
Peters. R., The Islamic School of Law: Evolution, Devolution, and Progress, red. P. Bearman, R. Peters, F.E. Vogel, Cambridge, Massachusetts 2005.

Piwko A., Rozwód w islamie, [w:] „Nurt SVD”, wydanie specjalne 2013.

Rao N.C., The impact of legislation on Marriage and Divorce under Hindu and Muslim Laws, „Acharya Nagarjuna” 2011, s. 253-255.

Sadowski M., Czy islam ma charakter totalitarny?, „Studia nad Autorytaryzmem i Totalitaryzmem” 39, 2017, nr 2, s. 105-116.

Sadowski M., Islam. Religia i prawo, Warszawa 2017.

Sadowski M., Matżeństwo w prawie islamu, Poznań 2015.

Sadowski M., Rozwód wedlug procedury talaq w prawie islamu, „Radca Prawny: Zeszyty naukowe” 2017, nr 3, s. 35-53.

Sahih al-Buchari, http://www.sahihalbukhari.com/sps/sbk/ (dostęp: 10.12.2004).

Schacht J., An introduction to Islamic law, Oxford 1982.

Sham S.I., Some Aspects of Marriage and Divcorce in Muslim Family Law, Punjab 2011, s. 32-33, http://pu.edu.pk/images/journal/szic/currentissue pdf/E-1\%20Shehza\%20sham\%20(Islamic\%20Law\%20of\%20Marriage\%20and\%20Divorce).pdf.

Shavit U., Shari'a and Muslim Minorities. The wasati and salafi approaches to fiqh al-aqalliyyat al-Muslima, Oxford 2015, s. 158-166.

Sinha R.K., Muslim Law, Allahabad 2003.

Sjukijajnen L.R., Prawo muzutmańskie i ustawodawstwo rodzinne krajów Arabskiego Wschodu, [w:] idem, Prawo muzutmańskie. Struktura i podstawowe instytucje, Warszawa 1990.

Sonneveld N., The implementation of the "khul' law" in Egyptian courts some preliminary results, „Recht van de Islam” 21, 2004, s. 21-35.

Sonneveld N., Khul divorce in Egypt. How family courts are providing a dialogue between husband and wife, ,Anthropology of the Middle East” 5, 2010, $\mathrm{nr} 2$.

Spencer K., Mahr as contract: internal pluralism and external perspectives, „Oñati Socio-Legal Series" 1, 2011, nr 2.

Sultan S., The Qur'an and Sayings of Prophet Muhammad: Selections Annotated \& Explained, Woodstock 2012.

Syed Jaffer H., Legal modernism in Islam: Polygamy and repudiation, „Journal of the Indian Law Institute" 7, October-December 1965, nr 4, s. 384-398.

Wardeh N.M., Rethinking polygamy in Islamic exegetical discourse, „International Journal of Arts \& Sciences" 09, 2016, $\mathrm{nr} 03$.

Wohidul M., Islam, dissolution of contract in Islamic law, „Arab Law Quarterly” 336, 1998. 